Article

\title{
Field Supervisory Test of DREB-Transgenic Populus: Salt Tolerance, Long-Term Gene Stability and Horizontal Gene Transfer
}

\author{
Nan Lu ${ }^{1, \dagger}$, Bing Wei ${ }^{1, \dagger}$, Yuhan Sun ${ }^{1}$, Xin Liu ${ }^{1}$, Shouyi Chen ${ }^{2}$, Wanke Zhang ${ }^{2}$, Yingzhi Zhang ${ }^{3}$ \\ and $\mathrm{Yun} \mathrm{Li}^{1}{ }^{1, *}$
}

1 National Engineering Laboratory for Tree Breeding, Key Laboratory of Genetics and Breeding in Forest Trees and Ornamental Plants of Ministry of Education, College of Biological Sciences and Technology, Beijing Forestry University, Beijing 100083, China;

E-Mails:1n_890110@163.com (N.L.); carolwei@126.com (B.W.); syh831008@163.com (Y.S.); 1x000610@163.com (X.L.)

2 Institute of Genetics and Developmental Biology, Chinese Academy of Sciences, Beijing 100101, China; E-Mails: sychen@genetics.ac.cn (S.C.); wkzhang@genetics.ac.cn (W.Z.)

3 Shandong Oriental Flower Co. Ltd., Dongying 257335, China; E-Mail: azhi2006@163.com

$\uparrow$ These authors contributed equally to this work and should be considered co-first authors.

* Author to whom correspondence should be addressed; E-Mail: yunli@bjfu.edu.cn; yunli63@gmail.com; Tel.: +86-10-62336094; Fax: +86-10-62336094.

Received: 18 December 2013; in revised form: 6 May 2014 / Accepted: 6 May 2014 / Published: 22 May 2014

\begin{abstract}
Improving saline resistance may be useful for reducing environmental susceptibility and improving yields in poplar plantations. However, the instability of genetically engineered traits and gene transfer reduce their usefulness and commercial value. To investigate whether the foreign gene is still present in the genome of receptor plants after seven years (i.e., long-term foreign gene stability and gene transfer), we randomly analyzed ten field-grown transgenic hybrid Populus ((Populus tomentosa $\times$ Populus bolleana $) \times P$. tomentosa) carrying the DREB1 gene from Atriplex hortensis. The results of PCR and tissue culture experiments showed that $A h D R E B 1$ was present in the transgenic trees and was still expressed. However, the transcriptional expression level had decreased compared with that four years earlier. The PCR results also indicated no foreign gene in the genomic DNA of microorganisms in the soil near the transgenic poplars, indicating that no
\end{abstract}


significant gene transfer had occurred from the transgenic poplars to the microorganisms at seven years after planting.

Keywords: Populus; transgenic hybrid; foreign gene stability; horizontal gene transfer

\section{Introduction}

Genetic engineering is a form of breeding known for its high efficiency and relative speed compared with traditional breeding. However, transgenic plants continue to be controversial, with one of the major issues being the stability of foreign genes. The fixed integration of foreign genes into the genomes of trees and their subsequent stable expression are essential for the further use of transgenic trees in forest tree breeding programs [1,2]. Unstable expression of a transgene in receptor plants can be due to both intrinsic factors, including a long lifecycle, difficulty in transformation and the general absence of sexual propagation before field release [3,4] and to the effects of the environment and stress [5].

Another major constraint on the use of genetically engineered plants is foreign gene transfer, including horizontal gene transfer (HGT) and vertical gene transfer. The latter process involves the transfer of foreign genes into offspring through sexual reproduction; this is also known as gene flow [6], and it has been reported in rice [7] and other plants [8]. In contrast, HGT refers to the transfer of genes between sexually incompatible organisms in a manner other than traditional reproduction. The hypothetical acquisition of antibiotic resistance genes from transgenic plants by bacteria through HGT is thought to be a negative factor in the application of genetic modification to trees, because of the problems caused by antibiotic-resistant bacteria [9]. Although the frequency of HGT from plants to bacteria is quite low [10], the transformation of Acinetobacter sp. BD413 with the neomycin phosphotransferase II (nptII) gene from transgenic plants has been reported [11]. DNA could be released into soil from decaying organs [12], and if such DNA was not rapidly degraded by extracellular DNAses, it could be taken up by competent bacteria [9]. Assessing the performance of genetically modified forests in the field should include the influence of foreign genes on the soil system, non-target insects and gene transfer [10]. Although there have been many biosafety studies and field supervisory tests for genetically modified plants, most have focused on agro-ecosystems, and there have been few studies regarding forest ecosystems. The strict evaluation of genetically modified trees in the field is necessary before their release into the ecosystem compared with annual transgenic crops in agro-ecosystems, because of the more complex planting environment, long growth cycle, extensive management and wider range of pollen dispersal [13]. Populus was the first transgenic tree produced, and it remains the most commonly used tree genus for the study of genetic modification [14-16]. However, compared with annual crops, much less is known about the long-term stability of foreign genes in forest trees, especially under field conditions. The uncertain stability of genetically engineered (GE) traits and potential negative influences on the environment have limited further commercial use; to date; only two transgenic trees have been deployed commercially [17].

Here, we report a field supervisory test associated with the stability of transgene expression in trees and gene transfer using transgenic poplars containing an exogenous gene, AhDREB1, which encodes 
a DREB-like transcription factor. AhDREB1, which was cloned from the halophyte, Atriplex hortensis, improves the salt tolerance of receptor trees significantly by regulating multiple saline and alkali stress resistance-related genes [18]. Such trees have been cultivated in the field since 2005. We investigated whether the foreign gene was still present in transgenic Populus and the stability of the AhDREB1 gene, including the expression of the exogenous gene at the transcriptional level and the salt tolerance of explants. To assess whether gene transfer occurred, the genomic DNA of kanamycin-resistant microorganisms in the soil was isolated and amplified. We aimed to provide a reference for the large-scale field release and deployment of GE tree breeding programs in the future.

\section{Materials and Methods}

\subsection{Characterization of Transformed Plants and Experimental Field Design}

A vector with a T-DNA region containing the $n p t I$ gene, which confers resistance to the antibiotic kanamycin, as a selection gene and the AhDREB1 gene [18] (Figure 1) was transformed into hybrid Populus $(($ Populus tomentosa $\times$ Populus bolleana $) \times$ P. tomentosa $)$ using Agrobacterium tumefaciens [18]. We obtained five independent lines with one or two copies of the gene. The transgenic poplar line, T46, was selected and planted in the field in 2005, together with non-genetically modified controls, and tested for high-level transgene expression and improved salt resistance under greenhouse conditions.

Figure 1. Structural drawing of $A h D R E B 1$ in the Ti expression vector.

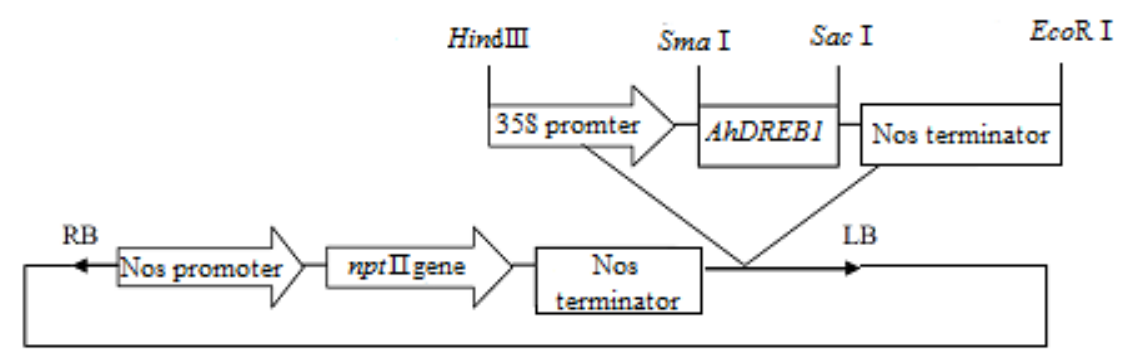

The experimental field was located in Dongying, Shan Dong Province, China (N 36 $56^{\prime}$, E $118^{\circ} 17^{\prime}$; the annual average temperature, rainfall, sunshine time and evaporation were $12.3{ }^{\circ} \mathrm{C}, 597 \mathrm{~mm}, 2590.1 \mathrm{~h}$ and $2032 \mathrm{~mm}$, respectively). This study was approved by the Chinese State Forestry Administration (Permit (2005) No. 07). All of the poplar types were cultivated in the field and were grown in saline soil and irrigated. The field was managed as for normal Populus. The trial field, which covered an area of $37,000 \mathrm{~m}^{2}$, contained 60 transgenic poplars and 20 controls distributed in rows (Figure 2). Fraxinus chinensis planted along an external edge was used as a buffer zone to prevent transgene flow through pollen dispersal. To investigate whether the transgenic trees could influence other plants in the field, weeds and other wild plants in the field were not removed. To reduce anthropogenic influences, the field was located far away from residential areas. 
Figure 2. Images of the trial field in 2005 (A and B). (C) The layout of the field. $\mathrm{C}$, non-transgenic control; $\mathrm{T}$, transgenic poplar. The spacing within the rows was $3 \mathrm{~m}$; the spacing between rows was $4 \mathrm{~m}$.

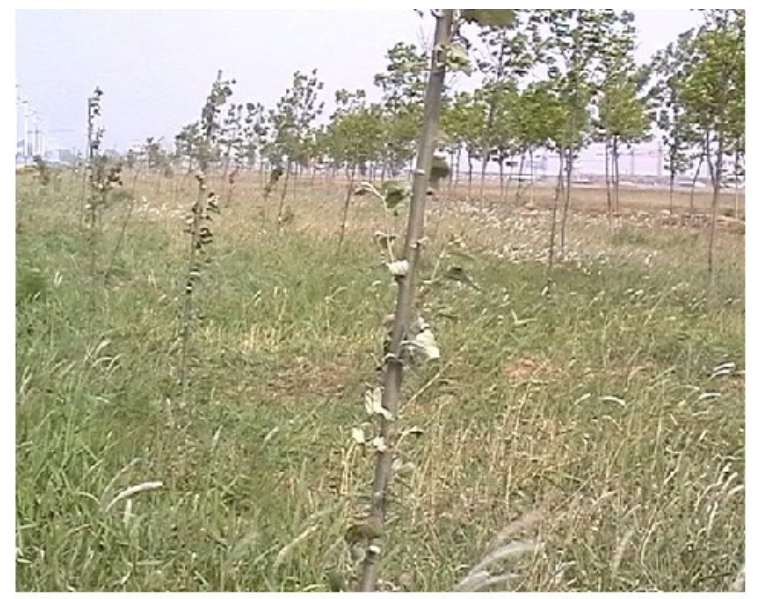

A

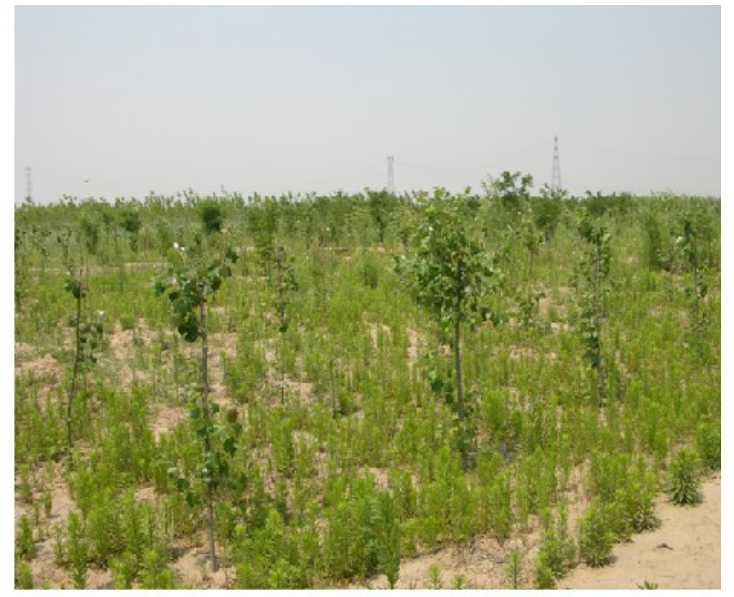

B

\begin{tabular}{|cccccccccc|}
\hline $\mathrm{C}$ & $\mathrm{C}$ & $\mathrm{C}$ & $\mathrm{C}$ & $\mathrm{C}$ & $\mathrm{C}$ & $\mathrm{C}$ & $\mathrm{C}$ & $\mathrm{C}$ & $\mathrm{C}$ \\
$\mathrm{T}$ & $\mathrm{T}$ & $\mathrm{T}$ & $\mathrm{T}$ & $\mathrm{T}$ & $\mathrm{T}$ & $\mathrm{T}$ & $\mathrm{T}$ & $\mathrm{T}$ & $\mathrm{T}$ \\
$\mathrm{T}$ & $\mathrm{T}$ & $\mathrm{T}$ & $\mathrm{T}$ & $\mathrm{T}$ & $\mathrm{T}$ & $\mathrm{T}$ & $\mathrm{T}$ & $\mathrm{T}$ & $\mathrm{T}$ \\
$\mathrm{T}$ & $\mathrm{T}$ & $\mathrm{T}$ & $\mathrm{T}$ & $\mathrm{T}$ & $\mathrm{T}$ & $\mathrm{T}$ & $\mathrm{T}$ & $\mathrm{T}$ & $\mathrm{T}$ \\
$\mathrm{T}$ & $\mathrm{T}$ & $\mathrm{T}$ & $\mathrm{T}$ & $\mathrm{T}$ & $\mathrm{T}$ & $\mathrm{T}$ & $\mathrm{T}$ & $\mathrm{T}$ & $\mathrm{T}$ \\
$\mathrm{T}$ & $\mathrm{T}$ & $\mathrm{T}$ & $\mathrm{T}$ & $\mathrm{T}$ & $\mathrm{T}$ & $\mathrm{T}$ & $\mathrm{T}$ & $\mathrm{T}$ & $\mathrm{T}$ \\
$\mathrm{T}$ & $\mathrm{T}$ & $\mathrm{T}$ & $\mathrm{T}$ & $\mathrm{T}$ & $\mathrm{T}$ & $\mathrm{T}$ & $\mathrm{T}$ & $\mathrm{T}$ & $\mathrm{T}$ \\
$\mathrm{C}$ & $\mathrm{C}$ & $\mathrm{C}$ & $\mathrm{C}$ & $\mathrm{C}$ & $\mathrm{C}$ & $\mathrm{C}$ & $\mathrm{C}$ & $\mathrm{C}$ & $\mathrm{C}$ \\
\hline
\end{tabular}

C

\subsection{Materials}

In 2009 and 2013, leaves, roots and stems were collected from ten random transgenic poplars (the trees selected in 2013 were the same as in 2009); all samples were obtained as three replicates. All of the leaves were taken near the tip of the lowest branches. All of the materials were snap-frozen in liquid nitrogen and stored at $-80^{\circ} \mathrm{C}$. Juvenile branches from the tops of the trees were collected and stored separately.

Soil samples were collected $\sim 30 \mathrm{~cm}$ from the trunk (three replicates: with the transgenic tree as the center of an equilateral triangle; the sampling points were at the three angles, ensuring that the soil samples were as close to the roots as possible and the same distance from the trunk).

\subsection{Screening for Kanamycin-Resistant Organisms}

Accurately weighed 1-g soil samples were diluted 10-fold with sterile water and then placed on a shaking incubator $(150 \mathrm{rpm})$ for $30 \mathrm{~min}$. They were then withdrawn in $1 \mathrm{~mL}$ of diluent into a transfer pipette and used to coat medium plates (beef extract-peptone medium for bacteria, Martin agar medium for actinomycetes and Gause's No. 1 synthetic medium base, modified for fungi) containing $50 \mathrm{mg} / \mathrm{L}$ kanamycin. After $1 \mathrm{~h}$ at room temperature, the plates were transferred to an incubator at $37^{\circ} \mathrm{C}$ 
for bacteria, $28{ }^{\circ} \mathrm{C}$ for actinomycetes and $25{ }^{\circ} \mathrm{C}$ for fungi. For screening, all kanamycin-resistant organisms were re-screened and expanded after incubation for 10 days.

\subsection{DNA Isolation and PCR Analyses}

Genomic DNA was isolated from the leaves of transgenic poplars using a Plant Genomic DNA Kit (Tiangen Biotech, Beijing, China), and the genomic DNA of the kanamycin-resistant bacteria was isolated using a TIANamp Bacteria DNA Kit (Tiangen Biotech). Genomic DNA was isolated from kanamycin-resistant actinomycetes and fungi using the cetyl trimethylammonium bromide method.

To investigate whether $A h D R E B 1$ was present in the genome of the transgenic poplars, PCR was performed in a reaction volume of $20 \mu \mathrm{L}$ containing $50 \mathrm{ng}$ of DNA, $1 \mu \mathrm{L}$ of each primer at $10 \mu \mathrm{M}$ (forward: 5'-GAAGAAAGATGTTGCTAATAATAAC-3'; reverse: 5'-AATAATAATATTCACTAA AAATGATC-3') and $10 \mu \mathrm{L}$ of Taq DNA polymerase (Takara Bio Inc., Otsu, Japan). The PCR profile consisted of denaturation at $94{ }^{\circ} \mathrm{C}$ for $5 \mathrm{~min}$, followed by 30 cycles of $94{ }^{\circ} \mathrm{C}$ for $30 \mathrm{~s}, 55{ }^{\circ} \mathrm{C}$ for $40 \mathrm{~s}$ and $72{ }^{\circ} \mathrm{C}$ for $1 \mathrm{~min}, 30 \mathrm{~s}$, with a final extension at $72{ }^{\circ} \mathrm{C}$ for $10 \mathrm{~min}$. Another set of primers for the $n p t I I$ gene (forward: 5'-GAACAAGATGGATTGCACGC-3'; reverse: 5'-GAAGAACTCGTCAA GAAGGC-3') was used to confirm whether $n p t I I$ had been transferred into the genomic DNA of kanamycin-resistant microorganisms. PCR was performed in a reaction volume of $20 \mu \mathrm{L}$ containing $50 \mathrm{ng}$ of DNA, $1 \mu \mathrm{L}$ of each primer at $10 \mu \mathrm{M}$ and $10 \mu \mathrm{L}$ of Taq DNA polymerase (Takara Bio Inc., Dalian, China). The PCR profile consisted of denaturation at $94{ }^{\circ} \mathrm{C}$ for $5 \mathrm{~min}$, followed by 35 cycles of $94{ }^{\circ} \mathrm{C}$ for $30 \mathrm{~s}, 54{ }^{\circ} \mathrm{C}$ for $30 \mathrm{~s}$ and $72{ }^{\circ} \mathrm{C}$ for $50 \mathrm{~s}$, with a final extension at $72{ }^{\circ} \mathrm{C}$ for $7 \mathrm{~min}$. Specific amplification of bacterial $16 \mathrm{~S}$ rDNA was used as a control in a reaction volume of $20 \mu \mathrm{L}$ containing $50 \mathrm{ng}$ of DNA, $1 \mu \mathrm{L}$ of each primer at $10 \mu \mathrm{M}$ (forward: 5'-ACGGGCGGTGTGTAC-3'; reverse: 5'-CCTACGGGAGGCAGCAG-3') and $10 \mu \mathrm{L}$ of Taq DNA polymerase (Takara Bio Inc., Dalian, China). The PCR profile consisted of denaturation at $94{ }^{\circ} \mathrm{C}$ for $5 \mathrm{~min}$, followed by 30 cycles of $94{ }^{\circ} \mathrm{C}$ for $30 \mathrm{~s}, 55^{\circ} \mathrm{C}$ for $40 \mathrm{~s}$ and $72{ }^{\circ} \mathrm{C}$ for $1 \mathrm{~min}$, with a final extension at $72{ }^{\circ} \mathrm{C}$ for $10 \mathrm{~min}$.

\subsection{Total RNA Extraction and Real-Time Quantitative PCR ( $q R T-P C R)$}

Total RNA was isolated from mature leaves, stems and roots of transgenic Populus using an EASYspin Plus Plant RNA Kit (Aidlab Biotechnologies, Beijing, China).

Total RNA $(5 \mu \mathrm{g})$ was reverse-transcribed using a TIANscript RT Kit (Tiangen Biotech, Beijing, China). qRT-PCR assays were performed in a final volume of $25 \mu \mathrm{L}$ containing $12.5 \mu \mathrm{L}$ of SYBR Premix EX Taq (Takara Bio Inc., Dalian, China), $0.2 \mu \mathrm{L}$ of each primer $(10 \mu \mathrm{M})$ and $2 \mu \mathrm{L}$ of cDNA as the template. To quantify the expression level of the target gene, the actin gene (GenBank Accession No. AY261523.1/U60491) was used as an internal control. The real-time PCR primers used were as follows: forward, 5'-TTTACCCAAGAACAGGACC-3', reverse, 5'-GTTTACGGAGGAATGAAG G-3'; and actin forward, 5'-CTCCATCATGAAATGCGATG-3', reverse, 5'-TTGGGGCTAGTGCTG AGATT-3'. The reactions were performed in triplicate using an OpticonTM2 machine (MJ Research, Waltham, MA, USA). The amplification parameters were: $94{ }^{\circ} \mathrm{C}$ for $30 \mathrm{~s}$, followed by 45 cycles of $94{ }^{\circ} \mathrm{C}$ for $12 \mathrm{~s}, 58^{\circ} \mathrm{C}$ for $30 \mathrm{~s}, 72^{\circ} \mathrm{C}$ for $45 \mathrm{~s}$ and $1 \mathrm{~s}$ at $81{ }^{\circ} \mathrm{C}$ for plate reading.

Differences in expression at the transcriptional level between 2009 and 2013 were assessed by a one-way ANOVA using SPSS software. 


\subsection{Transgenic Populus Tissue Culture}

Juvenile branches from the tops of ten transgenic poplars were collected as explants and were cultured on culture media after being sterilized with $0.1 \%$ mercury bichloride. The culture media for each phase were: $\mathrm{MS}+28 \mathrm{~g} / \mathrm{L}$ sucrose $+0.3 \mathrm{mg} / \mathrm{L} 6-\mathrm{BA}+0.1 \mathrm{NAA} \mathrm{mg} / \mathrm{L}$ for the primary culture, secondary culture and differentiation culture and $1 / 2 \mathrm{MS}+20 \mathrm{~g} / \mathrm{L}$ sucrose $+0.1 \mathrm{mg} / \mathrm{L} 6$-BA + $0.5 \mathrm{NAA} \mathrm{mg} / \mathrm{L}$ for rooting culture.

Transgenic poplar plants and non-transgenic tissue culture plantlets were transferred to differentiation or rooting medium with different $\mathrm{NaCl}$ contents $(0.2 \%-1.0 \%, 0.1 \%$ gradient $)$ with ten explants per treatment and ten repeats. The numbers of roots and the differentiation rates of the transgenic and non-transgenic plantlets were recorded once every 7 days. The proliferation rate was calculated as the number of differentiated explants/total number of explants $\times 100 \%$.

The data were analyzed by a two-way ANOVA to discriminate the proliferation rate and number of roots between the two groups after 21 days, 28 days and 35 days (proliferation rate) and after 21 days, 28 days, 35 days and 42 days (number of roots) using SPSS.

\section{Results and Discussion}

\subsection{Stability of the Foreign Gene after a Seven-Year Field Test}

The PCR results for ten randomly selected transgenic poplars (line T46), using primers specific for $A h D R E B 1$, are shown in Figure 2. All ten transgenic trees showed specific gene bands, while the non-transgenic controls lacked these specific bands (Figure 3). Thus, PCR-specific amplification indicated that $A h D R E B 1$ was still present in the genome.

Figure 3. Identification of $A h D R E B 1$ in the transgenic trees by PCR amplification. $-\mathrm{CK}$, DNA from non-transgenic poplars; +CK, plasmids containing AhDREB1; M, DNA marker (100-bp DNA ladder); 1-10, DNA from transgenic poplars.

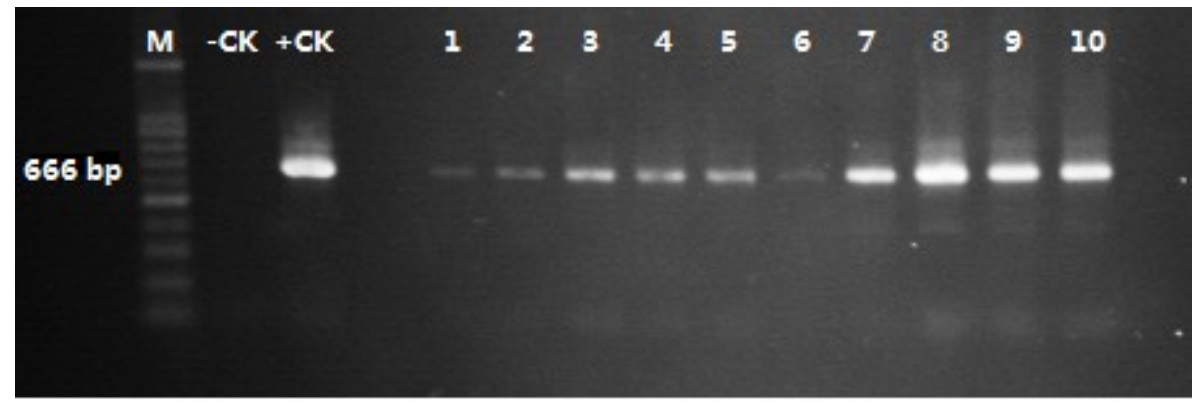

\subsection{Expression of AhDREB1 $m R N A$ after Three and Seven Years}

Real-time quantitative PCR analysis of different organs from five randomly selected transformed poplars (T1, T2, T3, T4 and T5) showed that the foreign genes were still expressed after cultivation in the field for seven years and that the transcript expression levels in each sample were 2.2-3.4-fold (2009) and 1.2-2.7-fold (2013) higher than the actin internal control. The expression levels in different organs showed no specificity. This may have been due to the promoter used to drive the exogenous 
gene: CaMV 35S causes the overexpression of foreign genes without significant tissue specificity in transgenic plants. Although all of the transgenic poplars were derived from the same clone, differential expression was seen between individuals. The samples from the five selected trees were collected and analyzed again after four years (2013). The AhDREB1 expression levels were decreased in 2013 compared with 2009 (Figure 4).

Figure 4. Analysis of $A h D R E B 1$ expression in different organs from five transgenic poplars in 2009 (blue) and 2013 (red). The transcriptional expression level of AhDREB1 in 2013 was slightly $(* 0.01<p<0.05, \alpha=0.05)$ or significantly $(* * p<0.01, \alpha=0.05$ ) decreased compared with 2009.
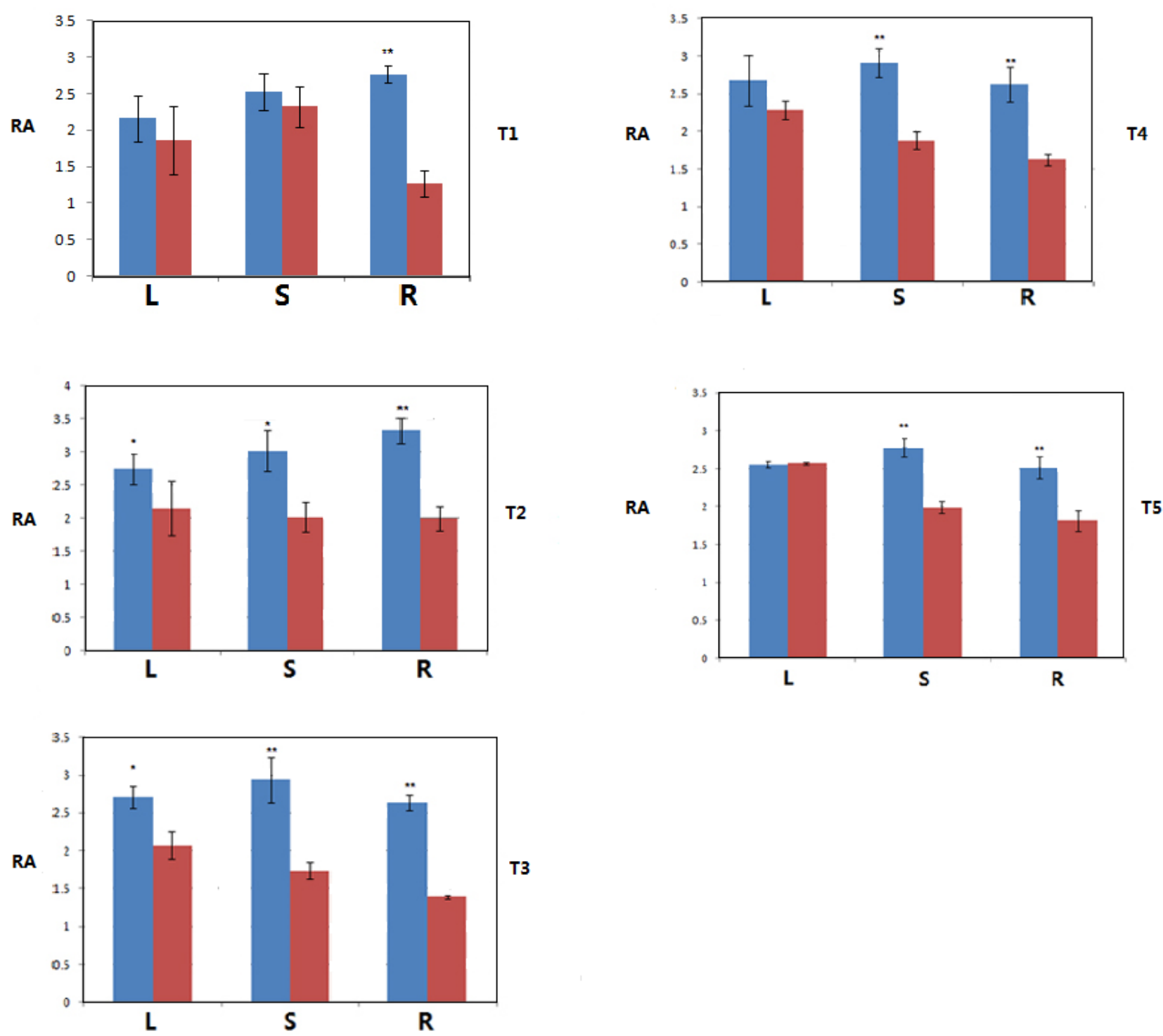

RA, relative expression level; L, leaf; S, stem; R, root.

\subsection{Salt-Tolerant Phenotype of the Transgenic Plants}

In vitro analyses revealed that the transgenic poplar plants were more tolerant of $\mathrm{NaCl}$ stress than their wild-type counterparts. The increased resistance of the transgenic plants to salt stress was examined by culturing tissues from transgenic and wild-type plants in culture media containing 
different concentrations of $\mathrm{NaCl}$. Tables 1 and 2 show the growth of transgenic and control tissues, respectively. Both transgenic and non-transgenic explants could grow and differentiate in medium containing $0.2 \%-0.3 \% \mathrm{NaCl}$. However, when the concentration of $\mathrm{NaCl}$ was increased to $0.5 \%$, the leaves of the non-transgenic plants began to turn yellow after 35 days (Figure 5A). All of the non-transgenic explants withered after 42 days in medium containing $0.6 \% \mathrm{NaCl}$. The transgenic explants demonstrated significant resistance to $\mathrm{NaCl}$ and still grew normally in the presence of $0.4 \%-0.5 \% \mathrm{NaCl}$ (Figure 5B). However, the transgenic seedling leaves gradually turned yellow with prolonged incubation times at $\mathrm{NaCl}$ concentrations of $0.5 \%-0.8 \%$. Explant growth began to be inhibited at $0.8 \% \mathrm{NaCl}$. The transgenic explants showed higher salt tolerance (two-way ANOVA, $p<0.01, \alpha=0.05)$.

Table 1. Proliferation at various $\mathrm{NaCl}$ concentrations.

\begin{tabular}{|c|c|c|c|c|c|}
\hline \multirow{2}{*}{$\begin{array}{c}\mathrm{NaCl} \\
\text { concentration } \\
(\%)\end{array}$} & \multirow{2}{*}{$\begin{array}{l}\text { Incubation } \\
\text { Time (Days) }\end{array}$} & \multicolumn{2}{|c|}{ Leaf Color } & \multicolumn{2}{|c|}{ Differentiation Rate (\%) } \\
\hline & & $\begin{array}{c}\text { Transgenic } \\
\text { Populus }\end{array}$ & Controls & $\begin{array}{c}\text { Transgenic } \\
\text { Populus }\end{array}$ & Controls \\
\hline \multirow{3}{*}{0.2} & 21 & Green & Green & 2.3 & 2.2 \\
\hline & 28 & Green & Green & 3.6 & 3.3 \\
\hline & 35 & Green & Green & 4.5 & 4.3 \\
\hline \multirow{3}{*}{0.3} & 21 & Green & Green & 2.4 & 2.2 \\
\hline & 28 & Green & Green & 3.3 & 3.5 \\
\hline & 35 & Green & Green & 4.6 & 4.2 \\
\hline \multirow{3}{*}{0.4} & 21 & Green & Green & 2.5 & 1.9 \\
\hline & 28 & Green & Green & 3.0 & 2.3 \\
\hline & 35 & Green & Yellow/green & 4.3 & 2.7 \\
\hline \multirow{3}{*}{0.5} & 21 & Green & Green & 2.2 & 0.7 \\
\hline & 28 & Green & Green & 3.2 & 0.9 \\
\hline & 35 & Green & Yellow & 4.1 & 1.1 \\
\hline \multirow{3}{*}{0.6} & 21 & Green & Green & 2.1 & - \\
\hline & 28 & Green & Yellow/green & 2.8 & - \\
\hline & 35 & Yellow/green & Yellow & 3.1 & - \\
\hline \multirow{3}{*}{0.7} & 21 & Green & Yellow & 1.6 & - \\
\hline & 28 & Yellow/green & Yellow & 1.9 & - \\
\hline & 35 & Yellow/green & Withered & 2.1 & - \\
\hline \multirow{3}{*}{0.8} & 21 & Yellow/green & Yellow & 0.6 & - \\
\hline & 28 & Yellow/green & Withered & 1.0 & - \\
\hline & 35 & Yellow & Dead & 0.7 & - \\
\hline \multirow{3}{*}{0.9} & 21 & Yellow/green & Withered & 0.2 & - \\
\hline & 28 & Yellow & Withered & 0.4 & - \\
\hline & 35 & Yellow & Dead & 0.2 & - \\
\hline \multirow{3}{*}{1.0} & 21 & Yellow/green & Withered & 0.2 & - \\
\hline & 28 & Yellow & Dead & 0.2 & - \\
\hline & 35 & Withered & Dead & 0.1 & - \\
\hline
\end{tabular}


Table 2. Rooting ability at various $\mathrm{NaCl}$ concentrations.

\begin{tabular}{|c|c|c|c|c|c|}
\hline \multirow{2}{*}{$\begin{array}{c}\mathrm{NaCl} \\
\text { concentration } \\
(\%) \\
\end{array}$} & \multirow{2}{*}{$\begin{array}{l}\text { Incubation } \\
\text { Time (Days) }\end{array}$} & \multicolumn{2}{|c|}{ Leaf Color } & \multicolumn{2}{|c|}{ Root Number } \\
\hline & & $\begin{array}{c}\text { Transgenic } \\
\text { Populus }\end{array}$ & Controls & $\begin{array}{c}\text { Transgenic } \\
\text { Populus }\end{array}$ & Controls \\
\hline \multirow{4}{*}{0.2} & 21 & Green & Green & 1.5 & 1.6 \\
\hline & 28 & Green & Green & 2.4 & 2.3 \\
\hline & 35 & Green & Green & 3.0 & 2.8 \\
\hline & 42 & Green & Green & 3.2 & 3.0 \\
\hline \multirow{4}{*}{0.3} & 21 & Green & Green & 1.7 & 1.5 \\
\hline & 28 & Green & Green & 2.5 & 2.5 \\
\hline & 35 & Green & Green & 2.7 & 2.9 \\
\hline & 42 & Green & Green & 3.1 & 3.2 \\
\hline \multirow{4}{*}{0.4} & 21 & Green & Green & 1.4 & 1.1 \\
\hline & 28 & Green & Green & 2.0 & 1.2 \\
\hline & 35 & Green & Yellow/green & 2.4 & 1.4 \\
\hline & 42 & Green & Yellow/green & 2.8 & 1.4 \\
\hline \multirow{4}{*}{0.5} & 21 & Green & Green & 0.7 & 0.4 \\
\hline & 28 & Green & Green & 1.5 & 0.4 \\
\hline & 35 & Green & Yellow/green & 1.5 & 0.5 \\
\hline & 42 & Yellow/green & Yellow/green & 2.1 & 0.5 \\
\hline \multirow{4}{*}{0.6} & 21 & Green & Green & 0.6 & 0.2 \\
\hline & 28 & Yellow/green & Yellow/green & 0.8 & 0.1 \\
\hline & 35 & Yellow/green & Yellow & 0.9 & 0.1 \\
\hline & 42 & Yellow & Withered & 0.9 & 0.1 \\
\hline \multirow{4}{*}{0.7} & 21 & Green & Yellow & 0.2 & - \\
\hline & 28 & Yellow/green & Yellow & 0.2 & - \\
\hline & 35 & Yellow/green & Withered & 0.2 & - \\
\hline & 42 & Yellow & Withered & 0.2 & - \\
\hline \multirow{4}{*}{0.8} & 21 & Yellow/green & Yellow & 0.2 & - \\
\hline & 28 & Yellow/green & Withered & 0.0 & - \\
\hline & 35 & Yellow & Dead & 0.1 & - \\
\hline & 42 & Withered & Dead & 0.1 & - \\
\hline \multirow{4}{*}{0.9} & 21 & Yellow/green & Withered & 0.1 & - \\
\hline & 28 & Yellow & Withered & - & - \\
\hline & 35 & Yellow & Dead & - & - \\
\hline & 42 & Withered & Dead & - & - \\
\hline \multirow{4}{*}{1.0} & 21 & Yellow & Withered & - & - \\
\hline & 28 & Yellow & Dead & - & - \\
\hline & 35 & Withered & Dead & - & - \\
\hline & 42 & Withered & Dead & - & - \\
\hline
\end{tabular}


Figure 5. Explants planted in medium containing $0.5 \% \mathrm{NaCl}$ for 35 days. The non-transgenic explants (A) began to turn yellow, while the transgenic explants (B) remained green.

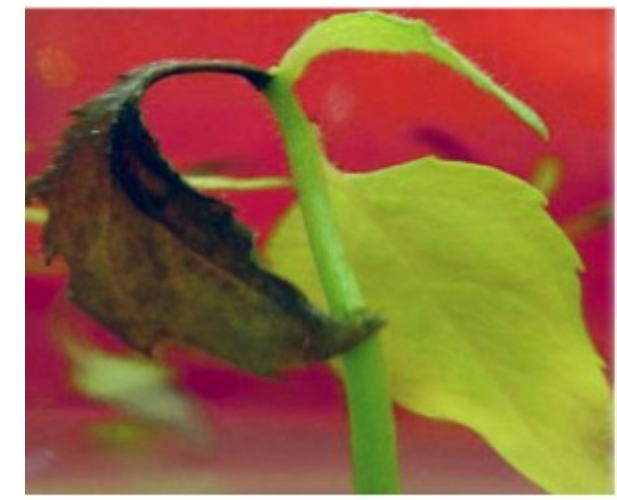

A

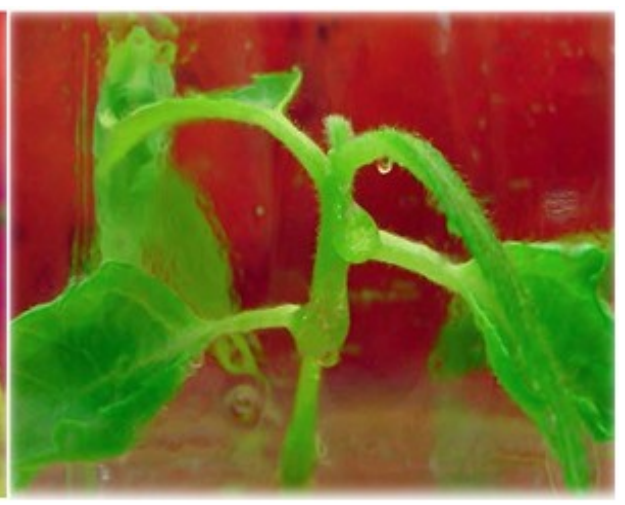

B

The plant growth parameters were analyzed after 35 days in culture. Overall, the differentiation rate and root numbers of the transgenic plants were similar to those of wild-type plants at $0 \% \mathrm{NaCl}$ (Figures 6 and 7). However, the differences between the transgenic and wild-type plants became significant with increasing $\mathrm{NaCl}$ levels (one-way ANOVA, $p<0.05, \alpha=0.05$ ). The differentiation rate of the wild-type plants decreased rapidly at $\mathrm{NaCl}$ concentrations above $0.3 \%$, while that of the transgenic plants was stable in the presence of $0.3 \%-0.5 \% \mathrm{NaCl}$ and began to decrease above $0.5 \% \mathrm{NaCl}$. The root numbers of the wild-type plants were also more significantly affected by $\mathrm{NaCl}$ stress after 35 days compared to the root numbers of the transgenic plants (one-way ANOVA, $p<0.05$, $\alpha=0.05$ ). The root numbers of the wild-type plants were rapidly reduced at more than $0.3 \% \mathrm{NaCl}$. However, the transgenic plants could still achieve normal rooting in the presence of $0.4 \% \mathrm{NaCl}$.

Figure 6. Proliferation at various $\mathrm{NaCl}$ concentrations $(0.2 \%-1 \%)$ after 35 days. A one-way ANOVA was used to discriminate between the proliferation rates of the two groups in the presence of different concentrations of $\mathrm{NaCl}(\%)$. The transgenic explants (blue line) showed a significantly higher proliferation rate than the wild-type plants (red line) $(* 0.01<p<0.05 ; * * p<0.01, \alpha=0.05)$.

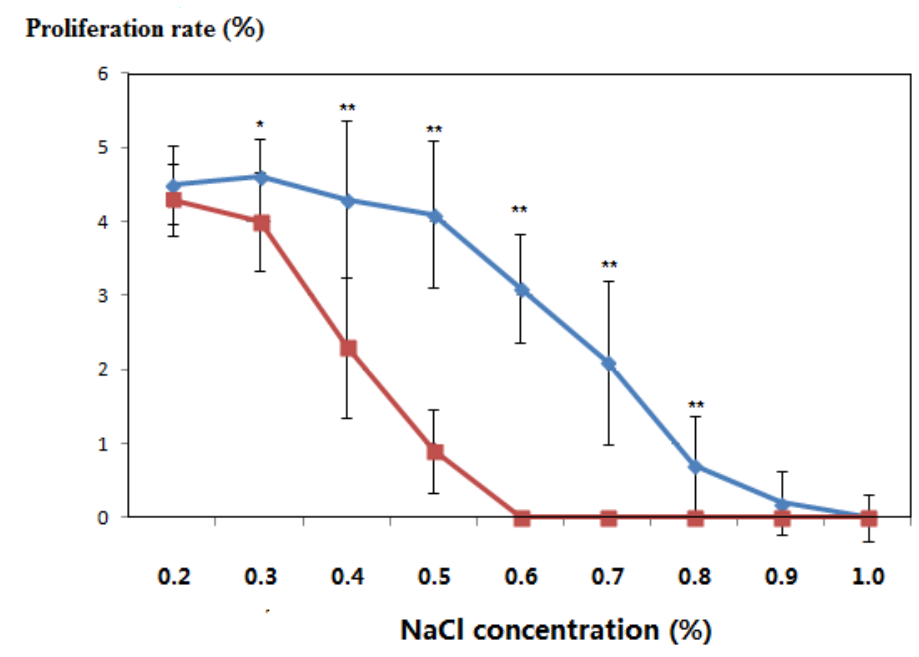


Figure 7. Rooting at various $\mathrm{NaCl}$ concentrations $(0.2 \%-1 \%)$ after 35 days. A one-way ANOVA was used to discriminate between the number of roots in the two groups in the presence of different concentrations of $\mathrm{NaCl}(\%)$. The transgenic explants (blue line) showed greater rooting ability in the presence of a high $\mathrm{NaCl}$ concentration than did the wild-type plants (red line) $(* 0.01<p<0.05 ; * * p<0.01, \alpha=0.05)$.

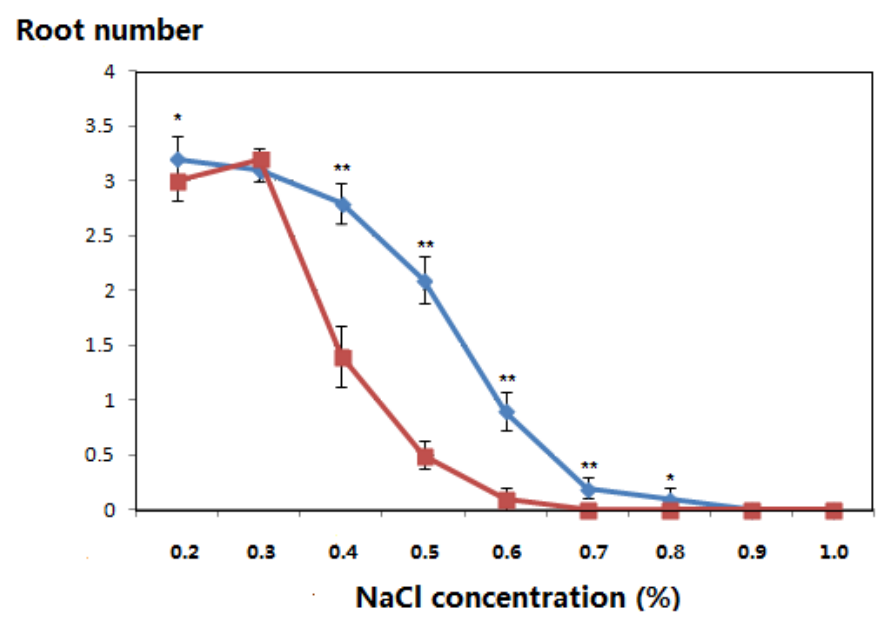

3.4. PCR Amplification of the NptII Gene in the Genomic DNA of Kanamycin-Resistant Microorganisms

We identified a total of 37 kanamycin-resistant microorganisms (16 bacteria, 12 actinomycetes and nine fungi) in the field in 2013. Our partial PCR amplification results are shown in Figure 8. In the positive control, a fragment of $750 \mathrm{bp}$ was amplified. NptII was not amplified from the genomic DNA of the kanamycin-resistant microorganisms; therefore, the kanamycin resistance was not due to the foreign gene in the transgenic poplar, but to the microorganisms themselves.

Figure 8. Assessment of horizontal gene transfer (HGT) to bacteria in the soil by PCR. $+\mathrm{CK}$, positive control; M, DNA marker (D2000 DNA marker); 1-8, samples. (A) PCR amplification of bacterial 16S rDNA as a control. All samples showed amplification of specific bands. (B) PCR amplification of the $n p t I I$ gene. No amplification was found in the samples.

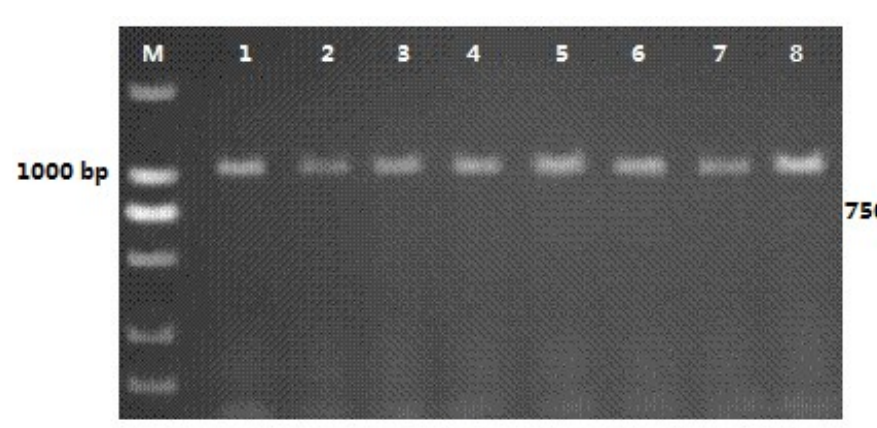

A

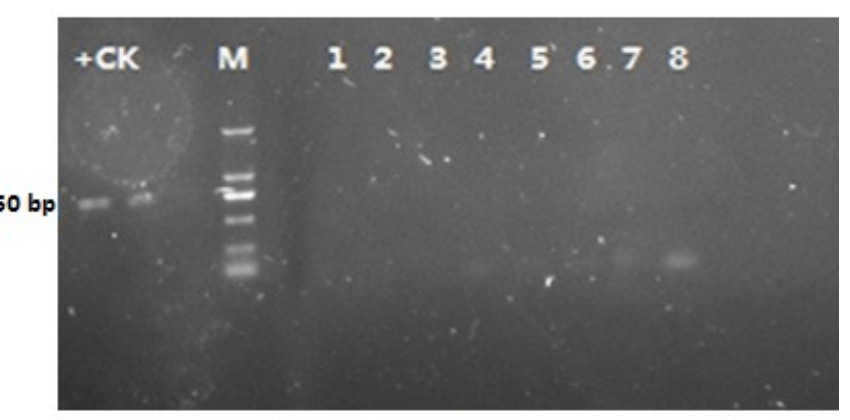

B 


\subsection{Discussion}

Long-term persistence and expression of a foreign gene in the recipient plant are the most important elements associated with the application of transgenic plants, especially for perennials, such as trees [19]. Jouanin et al. [20] reported gene silencing in transgenic poplars containing a double $35 \mathrm{~S}$ promoter, with almost no expression of the foreign gene. However, there have been many reports of long-term foreign gene expression [21,22]. Meilan et al. [23] reported the stability of $\beta$-glucuronidase (uidA) and $n p t \mathrm{II}$ in transgenic lines after more than four years in the field. Similarly, Li et al. [17] reported the long-term stability of herbicide resistance in poplars grown for more than eight years in the field. The long-term stability of the expression of two reporter genes, GFP and BAR, was also reported in poplar [24].

PCR amplification and real-time quantitative PCR using the samples from 2009 and 2013 showed that the $A h D R E B 1$ gene was present and still expressed in the transgenic poplars. However, the overall transcript level in 2013 was decreased compared with the level in 2009. In fact, the long-term stability of the expression of foreign genes in forest trees has been reported in several field experiments [25-27]. Therefore, it is difficult to conclude that the transcript level of foreign DNA would decrease with increasing culture time. The expression of a foreign gene is the combined result of integration, methylation status and the external environment [24]. Studies of transgenic maize (Zea mays L.) resistant to European corn borer (Ostrinia nubilalis L.) showed that water stress affected the levels of Bt protein expression [28]. Sachs et al. [29] found marked differential expression of the Cry gene in transgenic cotton planted in different locations. Bonade et al. [30] observed significant fluctuations in the amount of the foreign transcript in transgenic Populus alba L. in relation to the season, suggesting that the transcript level was responsive to environmental changes. As the external environment is not controlled in field tests, including the climate and human activity, it is unclear whether the decrease in transcript level was caused by internal or external factors or whether it was permanent or temporary. In a future study, we will focus on the variation in the transcript level of the foreign gene.

After cultivation in saline and alkaline soil for seven years, the survival rate of the transgenic poplars was $100 \%$, and they grew well. AhDREB1 expression improved the proline and chlorophyll contents, as well as the activities of peroxidase and superoxide dismutase by regulating the expression of several stress-responsive genes [18], reducing damage to the transgenic poplars under salt stress and improving their salt tolerance. Salt tolerance analysis of explants showed that the transgenic poplars retained their salt tolerance after three years, and no differences were found among individuals. Non-transgenic explants could not survive in the presence of $>0.3 \% \mathrm{NaCl}$, while the transgenic explants could root at $<0.7 \% \mathrm{NaCl}$; a negative effect was observed at $\geq 0.8 \%$. The performance of transgenic poplar under salt stress conditions in the present study was similar to that in an experiment performed in 2005 [17], suggesting that the salt resistance of transgenic poplar did not decrease after four years of field cultivation.

Gene transfer analysis showed that the AhDREB1gene had not introgressed from the transgenic poplars to microorganisms in the soil seven years after field planting. Our study is similar to those of Zhang et al. [31] and other field tests [32,33]. However, Hoffmann et al. [34] showed that an exogenous antibiotic resistance gene in transgenic oilseed rape could be transferred to Aspergillus niger. 
Except for the process of the Agrobacterium infection of dicotyledonous plants, other mechanisms of HGT between prokaryotes and eukaryotes remain unclear [35,36]. Natural transformation seems to be the most likely mechanism by which DNA is horizontally transferred from transgenic plants to bacteria [37]. Babett et al., (2007) [38] suggested that the number of naturally transformable cells in bulk or rhizosphere soil of potatoes may be quite low. However, it is difficult to determine whether this means a low possibility of HGT from transgenic plants to bacteria, because limited numbers of bacteria were isolated and tested, and the transformation conditions may not have been appropriate for all bacteria tested. Monier et al., (2007) [39] inferred that some DNA sequence homology may be essential for HGT. Simpson et al., (2007) [40] also showed that DNA sequence homology was an important factor influencing HGT. It has been demonstrated that, through homologous recombination or homology-facilitated illegitimate recombination, some bacteria could take up and stably integrate transgenic plant DNA [41]. If homologous DNA sequences are an important factor, the nature of the exogenous gene and receptor plants, as well as the diversity of soil ecology, should be taken into account in studies of HGT.

In this study, no significant gene transfer was found in the genomic DNA of kanamycin-resistant microorganisms isolated from the soil, which was similar as the results in 2009 [42]. However, because more than $90 \%$ of microorganisms cannot be cultured [43], a limited number of kanamycin-resistant microorganisms were tested from the soil. Total DNA from the soil should be isolated and analyzed in future studies.

\section{Conclusions}

The results of the present study demonstrate that the foreign gene, AhDREB1, was present in transgenic poplars and was still expressed seven years after planting. No significant gene transfer was found in the genomic DNA of kanamycin-resistant microorganisms. However, these results are relatively short term, and analyzing the influences of genetically modified trees on the ecological environment will be a long and complex process. Transgenic plant security and stability testing are also long-term projects; thus, longer-term observations and monitoring are required. In future experiments, we will focus on the reason for the apparent decline in transcription of the exogenous gene over time.

\section{Acknowledgments}

The authors appreciate the financial support from the National High Technology Research and Development Program of China (2013AA102703) and the Science and Technology Development Center of the State Forestry Administration Project (JJ-2012-04).

\section{Author Contributions}

Conceived and designed the experiments: Yun Li, Shouyi Chen, Wanke Zhang; performed the experiments: Nan Lu, Bing Wei, Yuhan Sun, Yingzhi Zhang, Xin Liu; Wrote the paper: Nan Lu, Bing Wei. 


\section{Conflicts of Interest}

The authors declare no conflict of interest.

\section{References}

1. Zeng, F.; Qian, J.; Luo, W.; Zhan, Y.; Xin, Y.; Yang, C. Stability of transgenes in long-term micropropagation of plants of transgenic birch (Betula platyphylla). Biotechnol. Lett. 2010, $32,151-156$.

2. Ahuja, M.R. Transgene stability and dispersal in forest trees. Trees 2009, 23, 1125-1135.

3. Han, K.H.; Ma, C.; Strauss, S.H. Matrix attachment regions (MARs) enhance transformation frequency and transgene expression in poplar. Transgenic Res. 1997, 6, 415-420.

4. Bradshaw, H.; Ceulemans, R.; Davis, J.; Stettler, R. Emerging model systems in plant biology: Poplar (Populus) as a model forest tree. J. Plant Growth Regul. 2000, 19, 306-313.

5. Choi, H.; Lemaux, P.; Cho, M.J. Increased chromosomal variation in transgenic versus nontransgenic barley (L.) plants. Crop Sci. 2000, 40, 524-533.

6. Bizily, S.P.; Rugh, C.L.; Meagher, R.B. Phytodetoxification of hazardous organomercurials by genetically engineered plants. Nat. Biotechnol. 2000, 18, 213-217.

7. Chen, L.J.; Lee, D.S.; Song, Z.P.; Suh, H.S.; Lu, B.R. Gene flow from cultivated rice (Oryza sativa) to its weedy and wild relatives. Ann. Bot. 2004, 93, 67-73.

8. Chèvre, A.M.; Eber, F.; Baranger, A.; Renard, M. Gene flow from transgenic crops. Nature 1997, 389, 924.

9. Gebhard, F.; Smalla, K. Monitoring field releases of genetically modified sugar beets for persistence of transgenic plant DNA and horizontal gene transfer. FEMS Microbiol. Ecol. 1999, $28,261-272$.

10. Schlüter, K.; Fütterer, J.; Potrykus, I. "Horizontal" gene transfer from a transgenic potato line to a bacterial pathogen (Erwinia chrysanthemi) occurs - If at all-At an Extremely Low Frequency. Nat. Biotechnol. 1995, 13, 1094-1098.

11. Gebhard, F.; Smalla, K. Transformation of Acinetobacter sp. strain BD413 by transgenic sugar beet DNA. Appl. Environ. Microbiol. 1998, 64, 1550-1554.

12. Widmer, F.; Seidler, R.; Donegan, K.; Reed, G. Quantification of transgenic plant marker gene persistence in the field. Mol. Ecol. 1997, 6, 1-7.

13. Kang, X.Y.; Liu, Z.M.; Li, S.G. Potential ecological risks of transgenic trees. Chin. J. Appl. Ecol. 2004, 15, 1281-1284.

14. Peña, L.; Séguin, A. Recent advances in the genetic transformation of trees. TRENDS Biotechnol. 2001, 19, 500-506.

15. Strauss, S.H.; DiFazio, S.P.; Meilan, R. Genetically modified poplars in context. For. Chron. 2001, 77, 271-279.

16. Brunner, A.M.; Nilsson, O. Revisiting tree maturation and floral initiation in the poplar functional genomics era. New Phytol. 2004, 164, 43-51.

17. Li, J.; Meilan, R.; Ma, C.; Barish, M.; Strauss, S.H. Stability of herbicide resistance over 8 years of coppice in field-grown, genetically engineered poplars. West. J. Appl. For. 2008, 23, 89-93. 
18. Du, N.; Liu, X.; Li, Y.; Chen, S.; Zhang, J.; Ha, D.; Deng, W.; Sun, C.; Zhang, Y.; Pijut, P.M. Genetic transformation of Populus tomentosa to improve salt tolerance. Plant Cell Tissue Organ Cult. 2011, 108, 181-189.

19. Frankenhuyzen, K.V.; Beardmore, T. Current status and environmental impact of transgenic forest trees. Can. J. For. Res. 2004, 34, 1163-1180.

20. Jouanin, L.; Goujon, T.; de Nadaï, V.; Martin, M.T.; Mila, I.; Vallet, C.; Pollet, B.; Yoshinaga, A.; Chabbert, B.; Petit-Conil, M. Lignification in transgenic poplars with extremely reduced caffeic acid $O$-methyltransferase activity. Plant Physiol. 2000, 123, 1363-1374.

21. Fladung, M.; Hoenicka, H.; Raj Ahuja, M. Genomic stability and long-term transgene expression in poplar. Transgenic Res. 2013, 22, 1167-1178.

22. Pilate, G.; Guiney, E.; Holt, K.; Petit-Conil, M.; Lapierre, C.; Leplé, J.C.; Pollet, B.; Mila, I.; Webster, E.A.; Marstorp, H.G. Field and pulping performances of transgenic trees with altered lignification. Nat. Biotechnol. 2002, 20, 607-612.

23. Meilan, R.; Auerbach, D.; Ma, C.; DiFazio, S.; Strauss, S. Stability of herbicide resistance and GUS expression in transgenic hybrid poplars (Populus sp.) during four years of field trials and vegetative propagation. HortSci. 2002, 37, 277-280.

24. Li, J.; Brunner, A.M.; Meilan, R.; Strauss, S.H. Stability of transgenes in trees: Expression of two reporter genes in poplar over three field seasons. Tree Physiol. 2009, 29, 299-312.

25. Borejsza-Wysocka, E.; Norelli, J.L.; Aldwinckle, H.S.; Malnoy, M. Stable expression and phenotypic impact of attacin $\mathrm{E}$ transgene in orchard grown apple trees over a 12 year period. BMC Biotechnol. 2010, 10, 41.

26. Zeng, F.; Xin, X.; Li, B.; Zhan, Y.; Yang, C. The stability of transgene expression and effect of DNA methylation on post transcriptional gene silencing (PTGS) in birch. Afr. J. Biotechnol. 2013, $10,8188-8193$.

27. Hawkins, S.; Lepl, J.C.; Cornu, D.; Jouanin, L.; Pilate, G. Stability of transgene expression in poplar: A model forest tree species. Ann. For. Sci. 2003, 60, 427-438.

28. Traore, S.B.; Carlson, R.E.; Pilcher, C.D.; Rice, M.E. Bt and non-Bt maize growth and development as affected by temperature and drought stress. Agron. J. 2000, 92, 1027-1035.

29. Sachs, E.; Benedict, J.; Stelly, D.; Taylor, J.; Altman, D.; Berberich, S.; Davis, S. Expression and segregation of genes encoding CryIA insecticidal proteins in cotton. Crop Sci. 1998, 38, 1-11.

30. Bonadei, M.; Zelasco, S.; Giorcelli, A.; Gennaro, M.; Calligari, P.; Quattrini, E.; Carbonera, D.; Balestrazzi, A. Transgene stability and agronomical performance of two transgenic Basta ${ }^{\circledR}$-tolerant lines of Populus alba L. Plant Biosyst.-Int. J. Deal. Asp. Plant Biol. 2012, 146, 33-40.

31. Zhang, C.; Hampp, R.; Nehls, U. Investigation of horizontal gene transfer in poplar/Amanita muscaria ectomycorrhizas. Environ. Biosaf. Res. 2005, 4, 235-242.

32. Kaldorf, M.; Fladung, M.; Muhs, H.J.; Buscot, F. Mycorrhizal colonization of transgenic aspen in a field trial. Planta 2002, 214, 653-660.

33. Hou, Y.J. Preliminary Study on the Ecological Safety Assessment of Transgenic Poplar. Ph.D. Thesis, Chinese Academy of Forestry, Beijing, China, 2008.

34. Hoffmann, T.; Golz, C.; Schieder, O. Foreign DNA sequences are received by a wild-type strain of Aspergillus niger after co-culture with transgenic higher plants. Curr. Genet. 1994, 27, 70-76. 
35. Won, H.; Renner, S.S. Horizontal gene transfer from flowering plants to Gnetum. Proc. Natl. Acad. Sci. 2003, 100, 10824-10829.

36. Kondo, N.; Nikoh, N.; Ijichi, N.; Shimada, M.; Fukatsu, T. Genome fragment of Wolbachia endosymbiont transferred to $\mathrm{X}$ chromosome of host insect. Proc. Natl. Acad. Sci. 2002, 99, 14280-14285.

37. Kay, E.; Vogel, T.M.; Bertolla, F.; Nalin, R.; Simonet, P. In situ transfer of antibiotic resistance genes from transgenic (transplastomic) tobacco plants to bacteria. Appl. Environ. Microbiol. 2002, $68,3345-3351$.

38. Richter, B.; Smalla, K. Screening of rhizosphere and soil bacteria for transformability. Environ. Biosaf. Res. 2007, 6, 91-99.

39. Monier, J.M.; Bernillon, D.; Kay, E.; Faugier, A.; Rybalka, O.; Dessaux, Y.; Simonet, P.; Vogel, T.M. Detection of potential transgenic plant DNA recipients among soil bacteria. Environ. Biosaf. Res. 2007, 6, 71-83.

40. Simpson, D.J.; Dawson, L.F.; Fry, J.C.; Rogers, H.J.; Day, M.J. Influence of flanking homology and insert size on the transformation frequency of Acinetobacter baylyi BD413. Environ. Biosaf. Res. 2007, 6, 55-69.

41. De Vries, J.; Wackernagel, W. Integration of foreign DNA during natural transformation of Acinetobacter sp. by homology-facilitated illegitimate recombination. Proc. Natl. Acad. Sci. 2002, 99, 2094-2099.

42. Wei, B.; Li, Y.; Du, N.X.; Liu, X. Transgene stability of transgenic hybrid of Populus[(Populus tomentosa $\times$ P. bolleana $) \times$ P. tomentosa] and its effect on soil microorganism. J. Nucl. Agric. Sci. 2009, 23, 1054-1059.

43. Amann, R.I.; Ludwig, W.; Schleifer, K.H. Phylogenetic identification and in situ detection of individual microbial cells without cultivation. Microbiol. Rev. 1995, 59, 143-169.

(C) 2014 by the authors; licensee MDPI, Basel, Switzerland. This article is an open access article distributed under the terms and conditions of the Creative Commons Attribution license (http://creativecommons.org/licenses/by/3.0/). 